\title{
Rapamycin prevents the impairments of social recognition induced by anti-P antibody in a murine model
}

The antiribosomal P antibody (anti-P) is detected predominantly in patients with systemic lupus erythematosus (SLE) ${ }^{1}$ and associated with a variety of neuropsychiatric manifestations (psychosis, mood disorders, cognitive decline, seizures and aseptic meningitis). ${ }^{23}$ A causal link between anti-P and the neuropsychiatric problems remains to be verified. Recently, anti-P has increasingly been associated with memory impairments. By passive transfer of anti-P into the brain of animals, previous experiments have revealed that hippocampus neurons are prime targets of anti-P, and spatial memory is impaired by the transferred anti-P. ${ }^{4} 5$ However, it remains unknown whether anti-P affects on the social memory (the memory of familiar conspecifics). Recently, the ventral CA1 region of hippocampus (vCA1) has been found to play a necessary and sufficient role in social memory. ${ }^{6}$ We, therefore, directly injected anti-P IgG $(1.7 \mathrm{mg} / \mathrm{mL}, 0.5 \mu \mathrm{L})$ isolated from SLE patient sera, or control IgG from normal individuals or vehicle (artificial cerebrospinal fluid) into vCA1 of normal mice (see details in online supplementary text), and at 24 hours later, we used the social discrimination task to evaluate the impact of anti-P in social memory of mice. As shown in figure $1 \mathrm{~A}$, a test mouse was placed in a plexiglass arena, and two pencilwire cups were placed on opposing corners (one was empty, the other enclosed a mouse). The test mouse habituated to the stimulus mouse during the first three sessions (5 min), rendering it 'familiar'. During the fourth session, a novel mouse was placed in the opposing cup and the three mice were in the same arena. The subject was tested for discrimination between the novel and familiar mouse. Mice received vehicle or control IgG injection showed a longer duration for interaction to a novel mouse than to a familiar mouse, whereas antiP-injected mice had no preference to a novel mouse, indicating an impairment of social memory (figure 1A,B). We also found that the olfactory and locomotor abilities were not altered in the mice (see online supplementary text and figures S1 and S2), suggesting that the anti-P injection did not cause sensory and motor deficits.

Next, we used a new cohort of mice to examine whether application of rapamycin can protect against the anti-Pinduced impairment. The mice were randomly divided into three groups: received daily intraperitoneal injection of rapamycin $(0.1 \mathrm{mg} / \mathrm{kg})$ for 7 days before anti-P injection (Rapa + anti-P), the same dose of saline injection and anti-P as the 
A
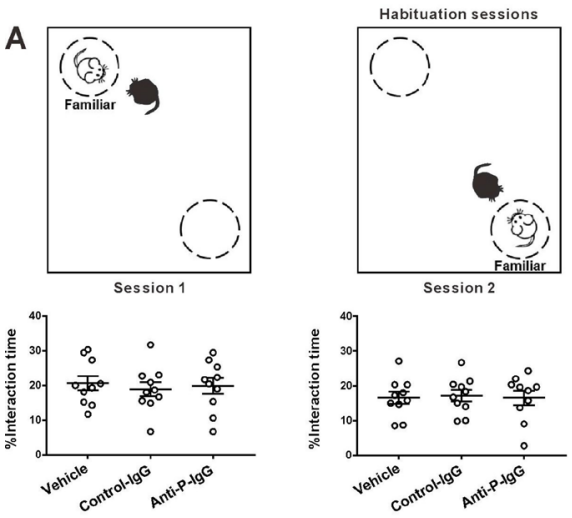

B
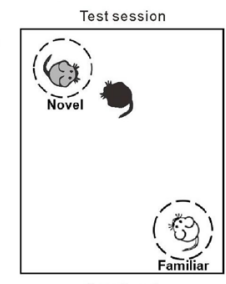

ession 4

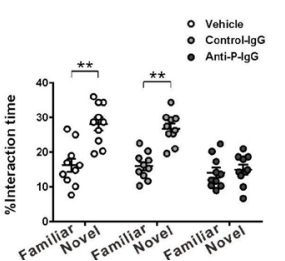

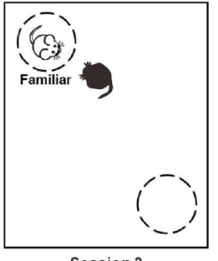

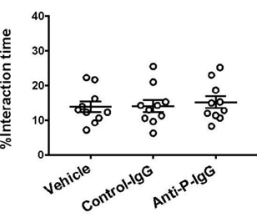

C

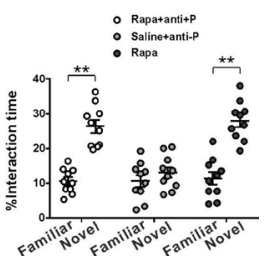

Figure 1 Behavioural schematic, and interaction time when the test mouse was interacting with the stimulus mice in habituation $(A)$ and test sessions (B). Effect of pretreatment of rapamycin. (C) All data are displayed as mean $\pm S E M ; n=10$. ${ }^{*} P<0.01$, t-test. anti-P, antiribosomal $P$.

control group (Saline +anti-P), and rapamycin alone (Rapa). The mice of Rapa + anti-P showed a significant discrimination between the familiar and novel mice, while those of saline +anti-P group did not (figure 1C), suggesting that rapamycin can prevent the social memory impairment induced by anti-P. The application of rapamycin alone has no significant effect on social memory. Here, we present the first evidence showing a detrimental role of anti-P in social memory and the preventive effect of rapamycin. Further systemic experiments are warranted to examine whether and how rapamycin can rescue the autoantibody-induced impairments in patients.

\section{Xuejiao Wang, ${ }^{1}$ Pingting Yang, ${ }^{2}$ Ling Qin $\odot{ }^{1}$ \\ 'Department of Physiology, China Medical University, Shenyang, China 2Department of Rheumatology and Immunology, First Affiliated Hospital, China Medical University, Shenyang, China}

Correspondence to Professor Ling Qin, Department of Physiology, China Medical University, Shen-yang 110122, China; qinlingling@yahoo.comDr Pingting Yang; yangpingtingting@163.com

\section{Handling editor Josef S Smolen}

Contributors XW was primarily responsible for experiment procedures, data collection and analysis; PY collected the clinical samples and assisted with manuscript preparation; LQ was primarily responsible for experimental design, data analysis and manuscript preparation. All authors contributed to and approved of the final version of the manuscript.

Funding This work was supported by the grants from National Nature Science Foundation of China under grant (31 671080 to LQ), Department of Science and Technology of Liaoning Province (2017225024 and 2018225111 to PY) and Department of Science and Technology of Shenyang (19-109-4-15 to PY).

Competing interests None declared.

Patient consent for publication Not required.

Ethics approval All procedures were approved by the Animal Care and Use Committee of China Medical University (No. KT2018060) and strictly adhere to the recommendations in the Guide for the Care and Use of Laboratory Animals of the National Institutes of Health.

Provenance and peer review Not commissioned; externally peer reviewed.

Open access This is an open access article distributed in accordance with the Creative Commons Attribution 4.0 Unported (CC BY 4.0) license, which permits others to copy, redistribute, remix, transform and build upon this work for any purpose, provided the original work is properly cited, a link to the licence is given, and indication of whether changes were made. See: https://creativecommons.org/ licenses/by/4.0/.

(C) Author(s) (or their employer(s)) 2020. Re-use permitted under CC BY. Published by BMJ.

- Additional material is published online only. To view please visit the journal online (http://dx.doi.org/10.1136/annrheumdis-2019-216563).

\section{Check for updates}

To cite Wang X, Yang P, Qin L. Ann Rheum Dis 2020;79:428-429.

Received 30 October 2019

Revised 22 November 2019

Accepted 1 December 2019

Published Online First 9 December 2019

Ann Rheum Dis 2020;79:428-429. doi:10.1136/annrheumdis-2019-216563

ORCID iD

Ling Qin http://orcid.org/0000-0001-8717-3833

\section{REFERENCES}

1 Sato T, Uchiumi T, Ozawa T, et al. Autoantibodies against ribosomal proteins found with high frequency in patients with systemic lupus erythematosus with active disease. J Rheumatol 1991;18:1681-4.

2 Bonfa E, Golombek SJ, Kaufman LD, et al. Association between lupus psychosis and anti-ribosomal P protein antibodies. N Engl J Med 1987:317:265-71.

3 Yoshio T, Masuyama J, Ikeda M, et al. Quantification of antiribosomal P0 protein antibodies by ELISA with recombinant PO fusion protein and their association with central nervous system disease in systemic lupus erythematosus. J Rheumatol 1995:22:1681-7.

4 Gaburo N, Timo-laria C, Timo-laria C, et al. Electrophysiological dysfunction induced by anti-ribosomal $\mathrm{P}$ protein antibodies injection into the lateral ventricle of the rat brain. Lupus 2017;26:463-9.

5 Bravo-Zehnder M, Toledo EM, Segovia-Miranda F, et al. Anti-Ribosomal P protein autoantibodies from patients with neuropsychiatric lupus impair memory in mice. Arthritis Rheumatol 2015;67:204-14.

6 Okuyama T, Kitamura T, Roy DS, et al. Ventral CA1 neurons store social memory. Science 2016:353:1536-41. 